\title{
PENGEMBANGAN GEL EKSTRAK ETANOL CABAI RAWIT (Capsicum frutescence $\mathrm{L}$ )
}

\author{
A. Hasrawati , Aztriana \\ Fakultas Farmasi Universitas Muslim Indonesia, Makassar \\ Email : a.hasrawati@umi.ac.id.
}

\begin{abstract}
Chili Pepper (Capsicum frutescence L) is a plant that can be used for the treatment of rheumatoid arthritis (RA). Chemical constituents contained in chili pepper is capsaicin, it was stimulate the nerves that can relieve pain. The purpose of this study was to determine the gel formulation of the ethanol extract of cayenne pepper which has optimal stability by using a variation of the base. In this study, the ethanol extract of cayenne pepper (2.5\%) was made using synthetic gel base (carbopol) and semisynthetic gel base (sodium carboxymethylcellulose). Evaluation of the physical stability was tested using stress conditions method. The stability parameters were determined by organoleptic, viscosity and flow type. The ethanol extract of chili pepper was successfully created gel form by using $5 \%$ of sodium carboxymethylcellulose and $1 \%$ of carbopol as a gelling agent. There was no significant change of two formulas in stability evaluation before and after of the storage condition.
\end{abstract}

Keywords : Capsicum frutescence L, chili pepper, ethanol extract, rheumatoid arthritis

\section{PENDAHULUAN}

Tulang merupakan suatu jaringan hidup yang terutama terdiri dari matriks ekstrasel organik yang diresapi oleh kristal hidroksiapatit. Dalam keadaan normal, pengendapan (deposisi, pembentukan tulang) tulang dan penyerapan (resorpsi, pembuangan) tulang berlangsung bersamaan sehingga tulang secara terus menerus mengalami remodeling, seperti orang memperbarui gedung dengan meruntuhkan temboknya untuk diganti yang baru ${ }^{1,2}$.

Rematik adalah istilah populer untuk berbagai gangguan dan nyeri pada sendi dan otot. Dari letaknya rematik terbagi menjadi dua yaitu rematik extra artikuler dan rematik artikuler. Rematik extra artikuler terjadi di luar sendi dengan gejala-gejala nyeri pada otot. Biasanya disebabkan oleh beban yang terlalu berat. Rematik extra rrtikuler tergolong ringan dan 
mudah diobati. Sedangkan Rematik artikuler adalah jenis yang berat dan cukup sulit diobati ${ }^{1,3}$.

Rheumatoid arthritis adalah jenis yang paling banyak terjadi di Indonesia dan paling susah diobati. Ditandai dengan adanya rasa nyeri pada sendi pada saat digerakkan dan pada tahap selanjutnya akan terjadi pembengkakan pada sendi yang bersangkutan. Sel darah putih akan keluar dari pembuluh darah menuju sendi yang terserang karena tubuh mengira telah terjadi peradangan. Dalam hal ini tubuh akan akan mengeluarkan zat leukotrin dan prostaglandin. COX2 berperan untuk merangsang produksi prostaglandin yaitu zat yang merangsang syaraf untuk merasakan sakit ${ }^{1,3,4}$.

Dalam dunia kedokteran dikenal 3 golongan obat yang digunakan untuk mengobati Rematik yaitu NSAID, GLUKOCORTICOID dan SAARD. Sayangnya sebagaimana umumnya obat-obatan kimiawi bisa menimbulkan berbagai efek samping dan selain bisa menyebabkan gangguan pada organ tubuh yang lain seperti ginjal ,hati dan jantung ${ }^{2,4}$. Bahan alam kini telah banyak menjadi pilihan bagi masyarakat sebagai alternative pengobatan. Tak terkecuali untuk pengobatan Arthritis rheumatoid ${ }^{5}$.
Salah satu obat tradisional yang dapat dimanfaatkan sebagai obat untuk penyakit tersebut diatas adalah kapsaisin. Kapsaisin merupakan bahan aktif utama yang terkandung dalam buah cabe terutama cabai rawit (Capsicum frutescence $L$ ) Dosis yang digunakan adalah $0.25 \% \quad 5,6,7$. Kapsaisin dapat diberikan baik melalui oral maupun topikal. Tetapi jika diberikan melalui oral akan menghasilkan efek terapi yang lain dan membutuhkan waktu yang lebih lama dalam memberikan efek. Sehingga untuk pengobatan reumatik, sediaan topikal (penggunaan pada kulit) merupakan pilihan yang paling baik. Dari beberapa bentuk sediaan topical, yang paling efektif untuk pengobatan rheumatoid arthritis adalah bentuk sediaan gel karena beberapa kelebihannya, yaitu memberikan sensasi dingin, tidak berminyak, mudah dicuci dengan air, mudah digunakan dan tidak membentuk lapisan yang oklusif ${ }^{8,9,10}$.

Berdasarkan hal tersebut diatas maka dibuatlah sediaan dalam bentuk gel yang merupakan bentuk sediaan topikal yang paling baik untuk penggunaan pada bagian luar tubuh terutama pada persendian, dengan menggunakan variasi basis gel untuk memperoleh sediaan gel yang paling 
stabil secara farmaseutik sehingga bisa digunakan untuk pengobatan RA.

\section{METODE PENELITIAN}

\section{Alat yang digunakan}

Cawan porselen, lumpang dan alu, gelas ukur, neraca analitik, termometer, peralatan gelas laboratorium, viskometer Brookfield, Wadah maserasi.

\section{Bahan yang digunakan}

Aquadest, Alkohol $96 \%$, ekstrak etanol cabai rawit, Metil paraben, Propilen glikol, $\mathrm{Na} \mathrm{CMC}$, Karbopol, Trietanolamin.

\section{Prosedur Penelitian}

\section{Penyiapan dan Pengolahan Sampel}

Cabai rawit sejumlah $2 \mathrm{Kg}$ disortasi basah (dicuci dan dibersihkan dari pengotor), lalu dikeringkan selama 17 hari. Sampel yang sudah kering kemudian disortasi untuk memisahkan yang mutunya baik dan dihilangkan dari zat pengotor, kemudian sampel dipotong-potong kecil untuk selanjutnya diekstraksi dengan metode maserasi menggunakan pelarut etanol. Proses maserasi dilakukan selama 7 hari dan diperoleh ekstrak cair sebanyak 2.2 liter. Ekstrak cair selanjutnya diuapkan untuk menghilangkan pelarut etanolnya hingga diperoleh ekstrak kental sebanyak 50.65 gram.

\section{Formulasi Gel Ekstrak Etanol Cabai Rawit (Capsicum frutescence L.)}

Gel ekstrak etanol Cabai Rawit dibuat dengan variasi bahan pembentuk gel yaitu natrium karboksimetilselulosa dan karbopol. Aquades digunakan sebagai pelarut, metil paraben sebagai pengawet dan propilen glikol sebagai humektan.

\section{Pembuatan Gel Ekstrak Etanol Cabai Rawit (Capsicum frutescence L.)}

Formulasi gel ekstrak etanol Cabai Rawit (Capsicum frutescence.L) dilakukan dengan menggunakan variasi bahan pembentuk gel. Formula A dibuat dengan menggunakan dasar gel Natrium Carboxymetilselulosa ( $\mathrm{Na}$ CMC). Dibuat dispersi $\mathrm{Na} \mathrm{CMC}$ dengan cara air suling dan metil paraben dipanaskan hingga suhu $75^{\circ} \mathrm{C}$ kemudian dimasukkan $\mathrm{Na}$ CMC dan diaduk hingga terbentuk dispersi yang kental dan jernih. Kemudian dimasukkan propilen glikol dan diaduk hingga homogen. Setelah itu ekstrak etanol cabai rawit dimasukkan kedalam dispersi di atas, lalu diaduk hingga homogen. Formula B dibuat dengan menggunakan dasar gel karbopol. Dibuat dispersi karbopol dengan cara air suling dan metil paraben dipanaskan hingga suhu $75^{\circ} \mathrm{C}$ kemudian dimasukkan karbopol dan 
diaduk hingga homogen. Selanjutnya ditambahkan TEA dan diaduk hingga terbentuk dispersi yang kental dan jernih. Dimasukkan propilen glikol dan diaduk hingga homogen. Setelah itu deimasukkan ekstrak etanol cabai rawit kedalam dispersi karbopol dan diaduk hingga homogen.

Evaluasi Sediaan Gel Ekstrak Cabai Rawit (Capsicum frutescence L.) Evaluasi kestabilan dengan kondisi dipaksakan

Untuk menguji kestabilan dari produk yang diformulasi dilakukan dengan metode kondisi dipaksakan (stress condition) untuk mempercepat peruraian dan mengurangi waktu yang dibutuhkan untuk pengujian. Sediaan gel diuji kestabilannya pada suhu $5^{\circ} \mathrm{C}$ dan $35^{\circ} \mathrm{C}$ selama 10 siklus, dimana tiap siklus adalah 12 jam.

\section{Evaluasi dengan beberapa parameter kestabilan fisika}

Evaluasi kestabilan fisika dari sediaan gel dilakukan dengan beberapa parameter fisika, yaitu pengukuran viskositas, pengujian organoleptik dan penentuan nilai yield.

\section{Pengujian organoleptik sediaan gel}

Pengujian organoleptik meliputi pemeriksaan bau, warna dan konsistensi dari formula sebelum dan sesudah kondisi dipaksakan.

\section{Pengukuran viskositas sediaan gel}

Sebanyak $100 \mathrm{ml}$ sediaan gel dimasukkan dalam beker gelas kemudian diukur viskositasnya dengan menggunakan viskometer brookfield yang dilengkapi spindle no. 62 pada kecepatan $50 \mathrm{rpm}$ dan dicatat hasilnya. Evaluasi dilakukan terhadap masing - masing formula sebelum dan sesudah penyimpanan dipercepat.

\section{Penentuan aliran}

Sebanyak $100 \mathrm{ml}$ sediaan gel dimasukkan ke dalam beker gelas kemudian diukur nilai yieldnya dengan menggunakan viskometer brookfield yang dilengkapi spindle no. 62 dengan berbagai kecepatan, yaitu $2 \mathrm{rpm}, 3$ rpm, 5, rpm, 10 rpm, 20 rpm, 30 rpm dan $50 \mathrm{rpm}$, lalu dicata hasilnya. Evaluasi dilakukan terhadap masingmasing formula sebelum dan sesudah penyimpanan dipercepat. 
Uji daya hambat ekstrak etil asetat daun binahong (Anredera coliforlia (Ten.) Steenis) terhadap pertumbuhan bakteri Staphylococcus aureus dan Escherichia coli.

\section{HASIL PENELITIAN}

Tabel 1. Rancangan formula gel ekstrak etanol cabai rawit (Capsicum frutescence $\mathrm{L}$ )

\begin{tabular}{ccc}
\hline \multirow{2}{*}{ Nama Bahan } & \multicolumn{2}{c}{ Konsentrasi (\%b/v) } \\
\cline { 2 - 3 } & Formula A & Formula B \\
\hline Ekstrak etanol cabai rawit & 2.5 & 2.5 \\
Natrium karboksimetilselulosa & 5 & - \\
karbopol & - & 1 \\
Trietanolamin & - & $9 s$ \\
Propilen glikol & 10 & 10 \\
Metil paraben & 0.02 & 0.02 \\
Air suling & Add 100 & Add 100 \\
\hline
\end{tabular}

Tabel 2. Hasil Pengamatan organoleptik sebelum dan sesudah kondisi dipaksakan

\begin{tabular}{cccc}
\hline \multirow{2}{*}{ Formula } & \multirow{2}{*}{ Jenis Pemeriksaan } & \multicolumn{2}{c}{ Kondisi } \\
\cline { 3 - 4 } & Bau & Sebelum & sesudah \\
\hline A & Warna & Khas & Khas \\
& Konsistensi & Kuning kecoklatan & Kuning kecoklatan \\
& Bau & Kental & Kental \\
\hline \multirow{2}{*}{ B } & Warna & Khas & Khas \\
& Konsistensi & Kuning kecoklatan & Kuning kecoklatan \\
& & Kental & Kental \\
\hline
\end{tabular}

\section{PEMBAHASAN}

Pada penelitian ini dibuat sediaan gel yang mengandung ekstrak etanol cabai rawit ( Capsicum frutescence L), karena adanya kandungan senyawa cabai rawit yaitu kapsaisin sebagai senyawa aktif dengan efek sebagai anti rematik. Gel ekstrak etanol cabai rawit dibuat menggunakan bahan pembentuk gel yang berbeda, yaitu natrium karboksimetilselulosa dan karbopol. Bentuk sediaan gel dipilih karena memiliki sensasi dingin pada saat aplikasi pada kulit dan mudah untuk dibersihkan.

Karbopol digunakan sebagai basis gel (sintetik) karena dapat menghasilkan gel satu fase yaitu terdiri dari makromolekul organik yang terdistribusi secara seragam dalam cairan yang tidak memperlihatkan batasan antara makromolekul terdispersi dan cairan ${ }^{10}$. Sedangkan metilselulosa merupakan basis gel semisintetik turunan selulosa yang akan menghasilkan sediaan yang jernih, transparan dan relatif bebas dari bentuk-bentuk serat ${ }^{8,9}$.

Setelah dibuat dua formula dengan basis gel yang berbeda dilakukan pengujian berdasarkan tiga parameter, yaitu pemeriksaan organoleptik, pengukuran viskositas dan penentuan tipe aliran. Pengujian kestabilan dilakukan dengan metode 
Uji daya hambat ekstrak etil asetat daun binahong (Anredera coliforlia (Ten.) Steenis) terhadap pertumbuhan bakteri Staphylococcus aureus dan Escherichia coli.

kondisi dipaksakan (stress condition) dengan penyimpanan pada suhu $5^{\circ} \mathrm{C}$ dan $35^{\circ} \mathrm{C}$ selama 10 siklus dengan masing - masing siklus berdurasi 12 jam. Tujuan dilakukan kondisi dipaksakan ini adalah untuk mengevaluasi stabilitas sediaan dan untuk mempersingkat waktu pengujian.

Pemeriksaan organoleptik dilakukan untuk mengetahui ada tidaknya pengaruh penyimpanan pada warna, bau dan konsistensi sediaan. Adapun hasil pengamatan yang diperoleh dari kedua formula gel arthritis rheumatoid dari ekstrak etanol cabai rawit (Capsicum frutescence.L) sebelum dan sesudah kondisi dipaksakan tidak mengalami perubahan warna, bau dan konsistensi sediaan. Hasil pengamatan organoleptik menunjukkan bahwa sediaan gel ekstrak etanol cabai rawit stabil pada penyimpanan.

Pada pengukuran viskositas sediaan digunakan alat viskometer brookfield. Viskositas sediaan diukur dengan menggunakan spindle no. 62 pada kecepatan $50 \mathrm{rpm}$ dan dilakukan sebanyak 3 kali replikasi.

Dari data yang diperoleh, dilakukan analisa secara statistik dengan menggunakan metode rancangan acak kelompok (RAK).
Hasil analisis menunjukkan bahwa viskositas dari formula $A$ dan formula $B$ tidak mengalami perubahan yang sangat signifikan pada kondisi sebelum dan sesudah kondisi dipaksakan. Hal ini menunjukkan bahwa adanya kondisi penyimpanan tidak mempengaruhi viskositas dari formula $A$ maupun formula $B$, yang menunjukkan bahwa baik formula $A$ maupun formula $B$ stabil pada penyimpanan.

Parameter terakhir yang dilakukan pada pengujian kestabilan adalah penentuan tipe aliran dari sediaan gel arthritis rheumatoid dari ekstrak etanol Cabai Rawit (Capsicum frutescence.L). Tipe aliran dapat dilihat dari rheogram serta nilai yield sediaan. Nilai yield diperoleh dari pengukuran viskositas sediaan pada beberapa rpm, kemudian dari data yang diperoleh dapat ditentukan tekanan geser (shearing stress) dan kecepatan geser (rate of shear). Dari rheogram diketahui bahwa tipe aliran gel yang dibuat adalah aliran plastis yaitu aliran yang memiliki nilai yield dan tidak melalui titik 0,0. Melalui analisa data statistik menunjukkan bahwa tidak terjadi perbedaan nyata pada sediaan sebelum dan sesudah kondisi dipaksakan. 
Uji daya hambat ekstrak etil asetat daun binahong (Anredera coliforlia (Ten.) Steenis) terhadap pertumbuhan bakteri Staphylococcus aureus dan Escherichia coli.

\section{KESIMPULAN}

Dari hasil penelitian ini diperoleh kesimpulan bahwa sediaan gel arthritis rheumatoid dari ekstrak etanol Cabai Rawit (Capsicum frutescence.L) dapat dibuat dengan menggunakan basis gel natrium karboksimetilselulosa (5\%) dan basis gel karbopol (1\%) dan memiliki kestabilan yang optimum.

\section{DAFTAR PUSTAKA}

1. Sherwood L. Fisiologi Manusia Dari Sel Ke Sistem. Edisi 2. Penerbit Buku Kedokteran EGC : Jakarta, 1996.

2. Sheil WC. 2010. Rheumatoid Arthritis (RA). Available from: http://www.medicinenet.com/rheum atoidarthritis/article.htm, diakses tanggal 28 April 2011.

3. Soumya R. Approach to the Patient with Musculoskeletal Disease. In: Coblyn, J.S., Bermas, B., Weinblatt, M., and Helfgott, S., Brigham \& Women's Experts' Approach to Rheumatology. Jones \& Bartlett Learning, 2011.
4. National Institute of Arthritis and Muskuloskeletal and Skin Disease (NIAMS). Questions and Answers about Arthritis and Rheumatic Disease. National Institute of Health : United States, 2008.

5. Tutik, 2010. Cabai rawit (Capsicum frutescence (http://forum.upi.edu/v3/ index .php ), diakses tanggal 10 Juli 2011.

6. Anonim, 2008, Ensiklopedia Indonesia, (Online), (http://id.wikipedia.org/wiki/Cabai), diakses tanggal 23 Juni 2011).

7. Anonim, 2010. Capsaicin, (http://en.wikipedia.org/wiki/Capsai cin), diakses tanggal 10 Juli 2011.

8. Ansel $\mathrm{CH}$. Pengantar Bentuk Sediaan Farmasi. Ul-Press: Jakarta, 1989.

9. Gennaro, A.R. Remington : The Science and Practice of Pharmacy $20^{\text {th }}$ edition. Philadelphia College of Pharmacy and Science : Philadelphia, 1990.

10.Lund W. The Pharmaceutical Codex Twelfth Edition. The Pharmaceutical Press : London, 1994. 